\title{
Penyakit Ginjal Kronis pada Anjing dan Kucing: Manajemen Terapi dan Diet
}

\author{
Chronic Kidney Disease in Dog and Cat: Treatment and Diet Management
}

\author{
Yanuartono, Alfarisa Nururrozi, Soedarmanto Indarjulianto \\ Departemen Ilmu Penyakit Dalam, Fakultas Kedokteran Hewan, Universitas Gadjah Mada \\ Jl. Fauna No.2, Karangmalang, Depok, Sleman. 55281 Yogyakarta \\ Email : yanuartono20@yahoo.com
}

\begin{abstract}
Chronic kidney disease is a progressive impairment of renal function and irreversible. The kidneys fail to maintain metabolism and fluid and electrolyte balance, causing uremia. This disease is a common problem in old cats and dogs that not detected by the owners up to $75 \%$ of kidney function is damaged. Clinical signs vary as polyuria, polidipsi, anorexia, vomiting, weight loss, pale mucous membranes, mouth ulceration, halitosis and acute blindness. Chronic renal failure is not curable so that the necessary medication management and proper diet in order to improve the quality of life and prolong the life of the animal.
\end{abstract}

Keywords : chronic renal failure, clinical signs, treatment, diet

\begin{abstract}
Abstrak
Penyakit ginjal kronis adalah gangguan fungsi ginjal yang progresif dan irreversible. Pada kondisi ini ginjal gagal mempertahankan fungsi metabolisme serta keseimbangan cairan dan elektrolit, sehingga menyebabkan uremia. Penyakit ini merupakan masalah umum pada anjing dan kucing yang sudah tua, serta seringkali tidak terdeteksi oleh pemilik hingga $75 \%$ dari fungsi ginjal mengalami kerusakan. Gejala klinis yang muncul bervariasi seperti poliuri, polidipsi, anoreksi, muntah, turunnya berat badan, membrana mukosa pucat, ulserasi mulut, halitosis dan kebutaan akut. Penyakit ginjal kronis tidak dapat disembuhkan sehingga diperlukan manajemen pengobatan dan diet yang tepat untuk dapat memperbaiki kualitas hidup dan memperpanjang hidup hewan.
\end{abstract}

Kata kunci : penyakit ginjal kronis, gejala klinis, pengobatan, diet

\section{Pendahuluan}

Fungsi utama ginjal adalah sebagai organ eksresi dan non eksresi (Price dan Wilson, 2005). Fungsi eksresi ginjal meliputi pengaturan $\mathrm{pH}$, konsentrasi ion mineral, komposisi cairan darah, eksresi produk akhir nitrogen dari metabolisme protein dan sebagai jalur eksretori untuk sebagian besar obat (Price dan Wilson, 2005). Fungsi non ekskresi adalah pengaturan tekanan darah, produksi eritrosit (Car, 2001) dan konversi vitamin D menjadi bentuk aktif (D3 atau 1-25-dihydroxycholecalciferol) (Polzin dkk., 2009).
Penyakit ginjal kronis adalah penurunan atau hilangnya kemampuan ginjal dalam mengeliminasi produk produk tidak terpakai, mengkonsentrasikan urin dan konservasi elektrolit (Neel dan Grindem, 2000). Biasanya kejadian penyakit ginjal kronis telah berlangsung dalam jangka waktu lebih dari 3 bulan (Polzin, 2011). Produk produk tidak terpakai tersebut bersifat toksik dan terakumulasi dalam aliran darah sehingga terjadi uremia dan azotemia. Akumulasi tersebut akan termanifestasi pada gejala klinis yang muncul setelah $75 \%$ ginjal mengalami kerusakan (Ettinger dan Feldman, 2005; Grauer, 2005). Gejala 
klinis tersebut antara lain adalah poliuri, polidipsi, anoreksi, muntah, turunnya berat badan, membrana mukosa pucat, ulserasi mulut (Dokuzeylul dan Kayar, 2016), halitosis dan kebutaan akut (Polzin dkk., 2005; Kralova dkk., 2009; Nelson dan Couto, 2009). Prognosis penyakit ini infausta karena biasanya melanjut menuju stadium akhir ginjal (Polzin dan Osborne, 1995). Penyakit ginjal kronis sering terjadi pada anjing maupun kucing yang sudah tua (Burkholder 2000; Kralova dkk., 2009), biasanya disebabkan oleh diabetes mellitus (Arzi dkk., 2008) hipertensi (Morar dkk., 2011) atau glomerulonephritis (Vaden, 2005).

Pengobatan penyakit ginjal kronis didasarkan atas gejala-gejala klinis yang muncul dan ditujukan untuk mengurangi penderitaan pasien. Pengobatan meliputi pemberian cairan pengganti (Wellman dkk., 2012), kalsitriol (Polzin dkk., 2005), antihipertensi/ ACE inhibitor(King dkk., 2006), hormoneritropoietik (Bloomberg dkk., 1992), suplementasi potassium (Sharon dkk., 1997), suplementasi antioxidant (Yu dkk., 2006), terapi alkalin (Allen, 2000), pembatasan diet P (Roudebush dkk., 2009), pemberian agen pengikat P (Bernachon dkk., 2014), dialisis (Crisp $d k k$., 1989) dan transplantasi ginjal (Bernsteen dkk., 1999). Tujuan utama pemberian diet adalah untuk memenuhi kebutuhan energi, menghilangkan gejala klinis akibat uremia, meminimalisir gangguan keseimbangan cairan, elektrolit, vitamin, mineral dan asam basa (McLeland dkk., 2014). Penyakit ginjal kronis bersifat ireversibel dan tidak dapat disembuhkan sehingga diperlukan diet yang tepat untuk dapat memperbaiki kualitas serta kenyamanan hidup dan memperpanjang hidup hewan (Bartges, 2012).

\section{Penyakit ginjal kronis}

Penyakit ginjal kronis adalah kelainan struktural atau fungsional dari satu atau kedua ginjal yang muncul dalam jangka waktu yang lama, bersifat ireversibel dan kemungkinan merupakan manifestasi akhir dari berbagai macam penyakit seperti penyakit penyakit infeksius, iatrogenik, metabolisme, kongenital, bahan toksik, traumatik, neoplasi, dan proses obstruksi yang menyerang ginjal (Lawson dkk., 2015). Sedangkan menurut Bargman dan Skorecki (2013), penyakit ginjal kronis atau penyakit renal tahap akhir merupakan gangguan fungsi renal yang progresif dan ireversibel dimana tubuh gagal untuk mempertahankan proses metabolisme dan keseimbangan cairan dan elektrolit, sehingga menyebabkan uremia.

Penyebab penyakit ginjal kronis sulit untuk ditentukan dalam kaitannya dengan stadium penyakit. Kerusakan dapat terjadi pada setiap bagian dari nefron, termasuk glomerulus, tubulus, jaringan interstitial atau pembuluh darah, yang dapat mengakibatkan kerusakan ireversibel dan hilangnya fungsi nefron (O’Neill dkk., 2013). Berdasarkan proses perjalanan penyakit dari berbagai penyebab pada akhirnya akan terjadi kerusakan nefron. Apabila nefron rusak, maka akan terjadi penurunan laju filtrasi glomerolus dan terjadilah penyakit ginjal kronik yang mana ginjal mengalami gangguan dalam fungsi eksresi dan fungsi non-eksresi. Penurunan laju filtrasi glomerolus mengakibatkan turunnya klirens kreatinin dan peningkatan kadar kreatinin serum. Hal ini menimbulkan gangguan metabolisme protein dalam usus yang mengakibatkan munculnya gejala klinis seperti anoreksia, nausea maupun vomitus. Peningkatan kreatinin dapat sampai ke otak sehingga mengakibatkan gangguan syaraf, terutama pada neurosensori (Surena, 2010). Dengan menurunnya filtrasi melalui glomerulus ginjal terjadi peningkatan fosfat serum dan penurunan kadar serum kalsium. Penurunan kadar kalsium serum 
menyebabkan sekresi parathormon dari kelenjar paratiroid. Penyakit ginjal kronis yang melanjut akan mengakibatkan peningkatan ekskresi protein dalam urine dan hipertensi (Kimmel dan Rosenberg, 2014).

Penyebab umum penyakit ginjal kronis pada anjing dan kucing adalah penyakit ginjal akut yang melanjut, pielonefritis, glomerulonefritis, nefrolitiasis dan ureterolitiasis. Penyebab yang berasal dari penyakit penyakit spesifik seperti FIP dan polycystic kidney disease ( $\mathrm{PKD}$ ) pada kucing, sindroma Fanconi, lyme disease pada anjing, amyloidosis ginjal, displasia ginjal dan limfoma ginjal (Reynolds dan Lefebvre, 2013; Hall dkk., 2014). Faktor predisposisi penyakit ginjal kronis pada anjing dan kucing meliputi umur, ras, diet dan penyakit periodontal (Lulich dkk.,1992; O’Neill dkk., 2013). Menurut Brown (2010), prevalensi penyakit ginjal kronis pada anjing adalah 0,5 $1 \%$, sedangkan pada kucing $1 \%$ - 3\% dan kejadian akan meningkat seiring dengan bertambahnya umur terutama pada kucing. Sedangkan menurut Lulich dkk. (1992), prevalensi kucing penderita penyakit ginjal kronis berumur lebih dari 10 tahun adalah sebesar 10\%, umur 15 tahun ke atas sekitar 30\% - 50 \% (Ross dkk., 2005) dan 28\% pada kucing diatas 12 tahun (Bartlett dkk., 2010).

Ras juga merupakan salah satu faktor predisposisi kejadian penyakit ginjal kronis. Prevalensi kejadian penyakit ginjal kronis dua kali lipat pada kucing jenis Maine Coon, Abyssinian, Siamese, Russian Blue, dan Burmese (Lulich dkk., 1992). Anjing ras yang memiliki kecenderungan mengalami penyakit ginjal kronis antara lain Cocker Spaniel (Lees dkk., 1998), Bull Terrier (Jones dkk., 1989) dan Boxer (Chandler dkk., 2007).

Penyakit periodontal umum terjadi pada kucing yang tua dan diduga merupakan salah satu faktor risiko terjadinya penyakit ginjal kronis pada kucing (Finch dkk., 2016) dan anjing (Bartlett dkk., 2010). Meskipun demikian faktor tersebut tampaknya bukan secara langsung tetapi karena penyakit periodontal dapat menyebabkan nyeri mulut sehingga akan menurunkan nafsu makan serta berat badan. Oleh sebab itu masih diperlukan penelitian lebih lanjut mekanisme terjadinya penyakit ginjal kronis akibat penyakit periodontal.

Salah satu faktor risiko yang dicurigai dapat mengakibatkan gagal ginjal kronis adalah pakan komersial. Pakan komersial yang mengandung protein tinggi dan bersifat asam akan menekan kalium sehingga mengakibatkan hipokalemia (Brown, 1996). Hipokalemia tersebut akan mengakibatkan kucing mengalami gagal ginjal kronis. Penelitian awal yang dilakukn oleh Dow dkk. (1987) pada kucing yang diberi diet acidifiers berakibat hipokalemia dan azotemia.

\section{Manajemen Terapi}

Kontrol status hidrasi

Terapi cairan pada penyakit ginjal kronis sangat penting artinya karena kondisi hipovolemik dan hipotensi adalah akibat dari kurangya intake cairan (Maddison dan Syme, 2010). Gangguan keseimbangan cairan pada penderita gagal ginjal yang mengalami poliuria dikompensasi dengan polidipsi. Oleh sebab itu, jika konsumsi air tidak mampu mengkompensasi maka akan timbul gejala dehidrasi (Ross, 2008). Dehidrasi mengakibatkan turunnya perfusi ginjal dan azotemia pre renal sehingga mengakibatkan semakin buruknya kondisi klinis dan laboratoris (Adams, 2004). Tujuan terapi cairan pengganti adalah mengembalikan volume cairan tubuh kearah normal dan mengurangi gejala klinis uremia (Lee dkk., 2005). Cairan pengganti dapat diberikan melalui beberapa rute seperti oral, intra vena (IV) atau sub kutan (SC). Jika aplikasi oral 
tidak memungkinkan maka dapat dilakukan secara IV, SC atau menggunakan feeding tube. Namun demikian tujuan utama terapi cairan pengganti secara SC bukan untuk menurunkan kadar BUN dan kreatinin tetapi lebih pada kenyamanan hewan penderita (Adams, 2013).

Koreksi dehidrasi diberikan tergantung dari derajad dehidrasi hewan. Jika derajat dehidrasi 5\% maka diberikan $50 \mathrm{ml} / \mathrm{kg} \mathrm{BB} / 12$ - 24 jam, kecuali hewan mengalami gangguan jantung sehingga pemberian harus diperlambat (Maddison dan Syme, 2010). Dosis perawatan sekitar $50 \mathrm{~mL} / \mathrm{kg} / \mathrm{hari}$, perlu ditambahkan dengan disesuaikan kondisi hewan. Cairan pengganti awal lebih diutamakan menggunakan larutan elektrolit yang seimbang seperti lactate Ringer's solution 75-100 ml / ekor kucing setiap hari atau setiap 2-3 hari tergantung kondisi (Adams, 2013). Pemberian cairan pengganti seperti Saline Solution (Natrium Klorida atau $\mathrm{NaCl}$ ) harus hati-hati, karena dapat meningkatkan konsentrasi $\mathrm{NaCl}$ yang mengakibatkan timbulnya oedema dan hipertensi (Roudebush dkk., 2010). Jika setelah pemberian cairan pengganti hewan mengalami oligouria (kurang dari 1-2 $\mathrm{ml} / \mathrm{kg}$ per jam), maka pemberian harus segera dihentikan guna menghindari terjadinya overhidrasi dan oedema (Powell, 2014). Setelah kondisi dehidrasi diperbaiki, pemberian cairan untuk pemeliharaan lebih tepat menggunakan cairan rendah $\mathrm{Na}(0,45 \% \mathrm{NaCl}$ dengan 2,5\% dextrose atau lactate Ringer's solution dengan 2,5\% dextrose) (Langston, 2009).

\section{Keseimbangan asam basa}

Asidosis metabolik adalah kondisi dimana keseimbangan asam-basa tubuh terganggu karena adanya peningkatan produksi asam atau berkurangnya produksi bikarbonat, ditandai dengan rendahnya kadar bikarbonat dalam darah. Apabila peningkatan keasaman melampaui sistem penyangga $\mathrm{pH}$, darah akan benar-benar menjadi asam (Schoolwerth dkk., 2006). Asidosis metabolik pada penyakit ginjal kronis bersifat multifaktorial, karena ginjal tidak mampu mensekresi asam $\left(\mathrm{H}^{+}\right)$yang berlebihan (de Brito-Ashurst dkk., 2009). Penurunan sekresi asam terjadi akibat tubulus ginjal tidak mampu mensekresi ammonia (NH3-) dan mengabsorbsi natrium bikarbonat (HCO3-) (Chen dan Abramowitz, 2014). Asidosis metabolik juga mengakibatkan penurunan eksresi fosfat dan asam organik (Elliott dkk., 2003).

Konsekuensi klinis yang terkait dengan asidosis metabolik meliputi peningkatan katabolisme protein, anoreksia, mual, muntah, lesu, penyusutan massa otot, dan kekurangan gizi (Elliott dkk., 2003; Wei Chen dan Abramowitz, 2014). Lebih dari 50\% kucing penderita penyakit ginjal kronis mengalami kondisi asidosis metabolik (Elliott dkk., 2003; de Morais dkk., 2008). Kucing penderita penyakit ginjal kronis yang diberi commercial renal diets (pakan komersial khusus penyakit ginjal) mampu meningkatkan konsentrasi bikarbonat sehingga mencegah terjadinya asidosis metabolik (Ross dkk., 2006). Jacob dkk. (2002) melaporkan bahwa 6 dari 38 anjing penderita penyakit ginjal kronis mengalami asidosis metabolik yang cukup berat. Penelitian oleh Elliot dkk. (2003) menunjukkan bahwa 5 dari 21 kucing mengalami acidaemia yang disertai penurunan fungsi ginjal. Satu dari 5 kucing tersebut mengalami asidosis metabolik tanpa disertai peningkatan konsentrasi kreatinin. Dengan demikian, data tersebut menunjukkan bahwa asidosis metabolik umumnya tidak terjadi sampai gagal ginjal stadium akhir.

Hewan penderita penyakit ginjal kronis yang mengalami asidosis metabolik mungkin dapat di 
koreksi dengan pemberian natrium bikarbonat oral dengan dosis $8-12 \mathrm{mg} / \mathrm{kgBB} 2-3$ kali sehari. Pakan dengan formulasi asam basa yang seimbang ditujukan untuk meminimalisir kejadian asidosis pada kucing penderita penyakit ginjal kronis (Sparkes dkk., 2016). Terapi tambahan jarang dilakukan kecuali terjadi perubahan pada konsentrasi bikarbonat darah dan konsentrasi total $\mathrm{CO}_{2}$ berada pada level $<16$ mmol/1. Suplementasi oral kalium sitrat (40-75 $\mathrm{mg} / \mathrm{kg}$ setiap 12 jam sebagai dosis awal) mungkin bermanfaat untuk mempertahankan bikarbonat darah atau total $\mathrm{CO}_{2}$ di kisaran level 16-24 mmol/ 1 (Sparkes dkk., 2016). Namun demikian, menurut Roudebush dkk. (2010) tidak ada uji klinis terkontrol yang menyatakan bahwa terapi alkalinisasi secara signifikan mampu memperbaiki dan meningkatkan kondisi anjing penderita penyakit ginjal kronis .

\section{Kontrol hiperfosfatemia}

Gangguan metabolisme kalsium dan fosfat merupakan salah satu komplikasi penyakit ginjal kronis yang harus mendapat perhatian, karena mempunyai peran yang sangat besar pada morbiditas dan mortalitas (Tomasello, 2008). Jika fungsi ginjal normal, secara klinis hiperfosfatemia jarang terjadi (Bellasi dkk., 2006;). Pada penyakit ginjal kronis, saat laju filtrasi glomeruli menurun hanya sampai tinggal 20\% dari normal maka akan timbul hiperfosfatemia dan selanjutnya akan merangsang peningkatan sekresi hormon paratiroid (Dibartola dan Willard, 2006).

Penyakit ginjal kronis adalah penyebab paling umum dari hiperfosfatemia pada kucing dan anjing dewasa (Kidder dan Chew, 2009). Pengobatan untuk kontrol hiperfosfatemia biasanya menggunakan intestinal phosphate binding agent seperti kalsium karbonat, kalsium asetat, alumunium hidroksi, sukrosa alumunium hidroksi (sucralfate), lanthanum karbonat sevelamer $\mathrm{HCl}$ dan epakitin (Houston, 2016). Dosis tepat yang direkomendasikan untuk alumunium hidroksi pada kucing tergantung dari level P darah, stadium penyakit, jenis pakan yang diberikan dan respon terhadap rasa alumunium hidroksi tersebut. Data dari Sparkes dkk. (2016) menyebutkan bahwa dosis intestinal phosphate binding agent awal untuk kucing adalah: aluminium hidroksida/karbonat 90 $\mathrm{mg} / \mathrm{kgBB} /$ hari, kalsium karbonat $90 \mathrm{mg} / \mathrm{kgBB} /$ hari, kalsium asetat $60-90 \mathrm{mg} / \mathrm{kgBB} /$ hari, lanthanum karbonat 30 - $90 \mathrm{mg} / \mathrm{kgBB} /$ hari dan sevelamer $\mathrm{HCl}$ 90 - $160 \mathrm{mg} / \mathrm{kgBB} /$ hari.

Intestinal phosphate binding agent bekerja paling efektif jika dicampur dengan pakan atau diberikan 2 jam setelah makan sehingga dapat mengikat P secara maksimal (Chew, 2015). Pada manusia dan kucing, suplementasi oral senyawa seperti chitosan, kalsium karbonat, dan kalium sitrat telah digunakan untuk penanganan hiperfosfatemia (Savicadkk., 2009).Pengobatan denganmenggunakan Pronefra ${ }^{\circledR}$ (kombinasi kalsium karbonat, magnesium karbonat, chitosan, vasoaktif peptida dan ekstrak Astragalus membranaceus) efektif menurunkan kadar fosfat dan kreatinin darah sehingga dapat digunakan untuk pengobatan penyakit ginjal kronis stadium awal pada kucing (Bernachon dkk., 2014). Kombinasi pembatasan diet $\mathrm{P}$ dan protein dengan atau tanpa penambahan intestinal phosphate binding agent (aluminium hidroksida) mampu menurunkan konsentrasi P maupun PTH dan memperpanjang hidup kucing penderita penyakit ginjal kronis (Barber dkk., 1999). Penelitian di Inggris dengan menggunakan sucralfate sebagai phosphate binding agent pada kucing tidak menunjukkan hasil yang memuaskan (Quimby dan Lappin, 2016). Namun jika memang akan digunakan untuk pengobatan, 
dosis yang direkomendasikan untuk kucing adalah 0,25 -0,5 g/kucing/12 jam (McLeland dkk., 2014). Pengobatan dengan Epakitin ${ }^{\circledR}$ (Vetoquinol Inc.) yang mengandung chitosan sebagai absorben (8\% ekstrak kepiting dan kulit udang), 10\% kalsium karbonat dan $82 \%$ laktosa dengan dosis 1 gram $/ 4 \mathrm{~kg}$ BB 2 kali sehari dicampur dengan pakan cukup efektif untuk anjing dan kucing. Pemberian Epakitin ${ }^{\circledR}$ pada kucing harus hati hati karena dapat menyebabkan hiperkalsemia (Houston, 2016).

\section{Kontrol renal secondary hyperparathyroidism}

Hiperfosfatemia pada penyakit ginjal kronis terjadi akibat kegagalan ginjal dalam mengekskresi fosfat, tingginya asupan fosfat atau peningkatan pelepasan fosfat dari ruang intraseluler (Barber dan Elliott, 1998). Ginjal merupakan organ ekskresi utama bagi fosfat, sehingga hampir tidak mungkin terjadi hiperfosfatemia pada fungsi ginjal yang masih normal. Hiperfosfatemia mengakibatkan berbagai konsekuensi seperti renal secondary hyperparathyroidism dan osteodistrofi renal (Nelson dan Feldman, 2004). Renal secondary hyperparathyroidism adalah suatu keadaan dimana terjadi hiperaktivitas kelenjar paratiroid dan peningkatan sekresi hormon paratiroid sebagai mekanisme kompensasi untuk mempertahankan kadar fosfat, kalsium dan kalsitriol dalam batas normal pada penderita penyakit ginjal kronis (Marx, 2000). Renal secondary hyperparathyroidism terjadi saat sintesis dan sekresi PTH menjadi berlebihan karena kerusakan ginjal (Nagode dkk., 1996).

Kalsitriol adalah Vitamin D dalam bentuk aktif dan berfungsi untuk mengatur penyerapan kalsium dari makanan yang sangat diperlukan untuk berbagai proses metabolisme tubuh serta proses pembentukan tulang (Brody, 1999). Kalsitriol bekerja melalui ikatan dengan reseptor sel spesifik paratiroid sehingga sintesis dan sekresi PTH dihambat (Silver dkk., 1985). Pemberian kalsitriol juga akan mengembalikan Ca ke level normal sehingga menghambat sekresi PTH dan selanjutnya mencegah terjadinya hiperplasi paratiroid (Chew dan Nagode, 1992).

Menurut Barber dan Elliott (1998) 84\% kasus penyakit ginjal kronis pada kucing menunjukkan peningkatan konsentrasi PTH plasma. Beberapa penelitian menunjukkan bahwa pemberian kalsitriol akan meningkatkan kadar Ca maupun $\mathrm{P}$ sehingga perlu dilakukan pemeriksaan kadar Ca dan $\mathrm{P}$ serum sebelum pemberiannya (Polzin dkk., 2005). Dengan demikian kalsitriol hanya dapat diberikan setelah kadar P serum normal (Barber dkk., 1999).

Pemberian kalsitriol oral dosis rendah dianggap aman dan efektif untuk mengontrol renal secondary hyperparathyroidism pada anjing. Sebaliknya, pemberian dosis rendah pada kucing tidak mepunyai pengaruh yang berarti dalam mengontrol renal secondary hyperparathyroidism (Hostutler dkk. 2006). Dosis rendah kalsitriol efektif apabila dimulai pada awal uremia sebelum renal secondary hyperparathyroidism melanjut. Pemberian kalsitriol dengan dosis 6,6 $\mathrm{ng} / \mathrm{kg}$ per hari selama 30 hari pada beberapa anjing penderita penyakit ginjal kronis menunjukkan penurunan sekresi PTH yang cukup berarti (Brown dan Finco, 1995). Penelitian Takahashi dkk. (2002) menunjukkan bahwa pemberian kalsitriol intravena maupun per oral efektif dalam mengontrol renal secondary hyperparathyroidism. Namun sebaliknya, studi eksperimental yang dilakukan oleh Kaplan dkk. (1978) menunjukkan bahwa pemberian kalsitriol dengan dosis (400 ng) IV selama 3 hari berturut turut tidak mampu menekan renal secondary hyperparathyroidism pada anjing yang mengalami uremia. Pada studi yang lain, pemberian kalsitriol 
dengan dosis $30-50 \mathrm{ng} / \mathrm{kgBB} /$ hari selama 14 minggu pada anjing yang diinduksi gagal ginjal meskipun mampu mengontrol hiperkalsemia namun mengakibatkan penurunan nafsu makan dan berat badan secara drastis (Dzanis dkk., 1991).

\section{Anemia}

Salah satu fungsi ginjal adalah menghasilkan eritropoetin untuk merangsang produksi sel darah merah oleh sumsum tulang. Eritropoetin diproduksi terutama di sel interstitial peritubular dari korteks ginjal bagian dalam dan medulla bagian luar ginjal (Erslev dan Besarab, 1997). Stimulus utama untuk sintesis eritropoetin adalah hipoksia ginjal, yang merangsang pengeluaran eritropoetin dari ginjal (Maiese dkk., 2008). Target kerja utama eritropoetin adalah sumsum tulang yang kemudian bekerja untuk meningkatkan produksi eritrosit. Semakin berat penyakit ginjal, semakin sedikit eritropoetin yang dihasilkan (Cook dan Lothrop, 1994). Patogenesis anemia akibat penyakit ginjal kronis bersifat kompleks dan multifaktorial namun demikian penyebab utamanya adalah turunnya kadar eritropoetin (Randolph, 2004). Anemia pada kasus penyakit ginjal kronis pada kucing menunjukkan derajat yang bervariasi (Elliott dan Barber,1998). Anemia dianggap sebagai faktor risiko dependen maupun independen pada proses penyakit ginjal kronis kucing (Chakrabarti dkk., 2012; Geddes dkk., 2015).

Sejumlah rhEPO telah diproduksi untuk pengobatan pada manusia seperti epoetin alfa, epoetin beta, darbepoetin alfa dan continuous erythropoeitin receptor activators tetapi obat tersebut juga bisa digunakan baik pada kucing maupun anjing (Chalhoub dkk., 2011). Terapi penyakit ginjal kronis dengan menggunakan Recombinant human erythropoeitin (rhEPO) pada kucing telah berhasil mengobati anemia non regeneratif. Kucing penderita menunjukkan peningkatan jumlah eritrosit, peningkatan berat badan, peningkatan nafsu makan, pertumbuhan rambut dan peningkatan aktivitas (Cowgill dkk., 1998; Randolph dkk., 2004; Chalhoub dkk., 2012). Penggunaan rhEPO dengan dosis $500 \mathrm{U}$ SC per hari selama tujuh hari kemudian dilanjutkan tiga kali seminggu selama beberapa bulan pada anjing penderita penyakit ginjal kronis menunjukkan perbaikan kondisi anemia. Selama terapi perlu dilakukan pemantauan yang seksama pada status $\mathrm{Fe}$ dan tekanan darah karena salah satu efek samping dari pemberian rhEPO adalah meningkatnya tekanan darah (Bloomberg dkk., 1992). Namun demikian menurut Cowgill dkk. (1998), setelah pemberian beberapa minggu rhEPO, tubuh akan menghasilkan antibodi anti rhEPO sehingga pengobatan hanya bersifat sementara. Dampak yang sama juga terlihat pada pemberian recombinant feline erythropoeitin (fEPO) pada kucing penderita penyakit ginjal kronis (Randolph dkk., 2004). Pada anjing terjadi hal yang sama dimana 50\% anjing yang diterapi dengan rhEPO membentuk antibodi anti rhEPO dan mengalami anemia berat karena kemungkinan rhEPO menginduksi aplasia sel darah merah (Cowgill, 1991). Hal tersebut kemungkinan karena adanya perbedaan sekuensing urutan basa asam amino sebesar $18,7 \%$ sehingga berpotensi imunogenik pada anjing (MacLeod dkk., 1998). Menurut Chalhoub dkk. (2011), 12\% kucing memberikan respon kesembuhan yang baik setelah pemberian darbepoietin dengan dosis awal dosis $0,45 \mathrm{mg} / \mathrm{kg}$ sekali seminggu. Sedangkan pemberian darbepoietin dengan dosis dosis 1,0 $\mathrm{mg} / \mathrm{kg}$ sekali seminggu, $62 \%$ kucing memberikan respon kesembuhan yang baik. Setelah PCV meningkat menjadi kisaran 25 - 35\%, 
pemberian darbepoietin menurun frekuensi menjadi setiap 2-3 minggu.

\section{Hipertensi}

Peran ginjal dalam pengaturan tekanan darah adalah melalui pengaturan volume cairan ekstraseluler dan sekresi renin. Sistem ReninAngiotensin merupakan sistem endokrin yang penting dalam pengontrolan tekanan darah (Atlas, 2007). Renin disekresi oleh juxtaglomerulus aparantus ginjal sebagai respon penurunan perfusi glomerulus, penurunan asupan garam, ataupun respon dari sistem saraf simpatetik (Thibodeau, 1999). Mekanisme terjadinya hipertensi adalah melalui terbentuknya angiotensin II dari angiotensin I oleh angiotensin I-converting enzyme (ACE) (Watanabe dan Mishina, 2007). Angiotensin I-converting enzyme memegang peranan fisiologis penting dalam mengatur tekanan darah. Darah mengandung angiotensinogen yang diproduksi hati, yang oleh hormon renin dari ginjal akan diubah menjadi angiotensin I. Oleh ACE yang terdapat di paru-paru, angiotensin I diubah menjadi angiotensin II. Angiotensin II berpotensi besar meningkatkan tekanan darah karena bersifat sebagai vasoconstrictor melalui dua jalur, yaitu meningkatkan sekresi hormon antidiuretik (ADH) dan menstimulasi sekresi aldosteron dari korteks adrenal (Mitani dkk., 2013).

Penyakit ginjal kronis merupakan salah satu penyebab terjadinya hipertensi pada hewan kecil yang sudah tua (Jepson dkk., 2007). Penelitian Kobayashi dkk. (1990) menunjukan bahwa prevalensi hipertensi akibat penyakit ginjal kronis pada kucing mencapai $60 \%$. Sedangkan penelitian Syme dkk. (2002) menunjukan bahwa 18\% kucing terdiagnosa penyakit ginjal kronis menderita hipertensi. Prevalensi hipertensi akibat penyakit ginjal kronis pada anjing pada penelitian Cortadellas dkk. (2006) menunjukkan angka sebesar 62\%, sedangkan penelitian Bodey dkk. (1996) sebesar 9\%. Penelitian lain menunjukkan bahwa hipertensi dapat mengakibatkan kebutaan pada kucing penderita penyakit ginjal kronis (Morgan, 1986).

Angiotensin I-converting enzyme inhibitor (ACEi) dan calcium channel blocker (CCB) sudah sering digunakan untuk anjing dan kucing penderita hipertensi (Brown dkk., 2007). Termasuk dalam kelompok ACEi adalah benazepril, enalapril dan temocapril. Angiotensin I-converting enzyme inhibitor menghambat kerja ACE secara kompetitif (Lopez-Sendón dkk., 2004), dengan cara menghambat pembentukan angiotensin II (Sweitzer, 2003). Sedangkan yang termasuk golongan CCB adalah amlodipine (Maddison dan Syme, 2010). Menurut Litman (1994) terapi hipertensi pada kucing dapat menggunakan diuretik, calcium channel blocker (CCB), $\beta$ blocker dan ACEi serta diet rendah garam. Angiotensin I-converting enzyme inhibitor biasanya direkomendasikan sebagai obat pilihan awal (Ettinger dkk., 1998).

Laporan kasus oleh Yabuki dkk. (2011) menunjukkan bahwa pemberian generasi baru ACEi (temocapril) mampu menurunkan tekanan darah pada anjing penderita penyakit ginjal kronis stadium awal. Pemberian benazepril hidrokorida pada kucing per oral dengan dosis harian 2,5 atau $5 \mathrm{mg}$ ( 0,92-2,0 mg / $\mathrm{kg} /$ hari ) selama 2 atau 3 minggu cukup efektif pada penanganan hipertensi akibat penyakit ginjal kronis (Watanabe dan Mishina, 2007). Hasil penelitian Mizutani dkk. (2006) menunjukkan bahwa pemberian tablet benazepril dengan dosis $0,5-1,0 \mathrm{mg} / \mathrm{kg} \mathrm{BB}$, sehari sekali mampu menghambat laju kerusakan ginjal dan memperpanjang umur kucing (Mizutani dkk., 2006). Penelitian oleh Morar dkk. (2009) pada kucing 
berumur 7 - 14 tahun yang didiagnosa penyakit ginjal kronis dan diberi amlodipine dengan dosis 0,1-0,2 mg/ $\mathrm{kg}(0,625 \mathrm{mg} / \mathrm{kucing})$ menunjukkan bahwa tekanan darah menurun secara signifikan. Hasil yang sama juga ditunjukkan oleh penelitian Maddison dan Syme (2010) yang menyatakan bahwa dosis awal amlodipine 0,625 $\mathrm{mg}$ (1/8 tablet)/kucing/hari mampu menurunkan tekanan darah kucing penderita penyakit ginjal kronis. Namun jika dosis tersebut gagal menurunkan tekanan darah (yaitu untuk < 165 mmHg) maka dosis dua kali lipat menjadi 1,25 mg (1/4 tablet)/kucing/hari. Dosis dua kali lipat tersebut mampu menurunkan tekanan darah di hampir semua kucing.

\section{Kontrol hipokalemia}

Kalium adalah kation intraseluler utama dalam sel mamalia dan terutama bertanggung jawab untuk pemeliharaan volume intraseluler (DiBartola dan de Morais, 2006). Keseimbangan kalium dipertahankan terutama lewat regulasi ekskresi ginjal. Ketidakseimbangan kalium $(\mathrm{K}+)$ merupakan salah satu gangguan serius yang dapat terjadi pada gagal ginjal. Frekuensi kejadian hipokalemia akibat penyakit ginjal kronis lebih sering terjadi pada kucing dibandingkan dengan anjing (Ross, 2008). Hipokalemia dapat menyertai poliuria pada penyakit ginjal kronis awal, terutama pada penyakit-penyakit pada tubulus ginjal. Akan tetapi hiperkalemia selalu akan timbul bila pasien mengalami oligouria pada penyakit ginjal kronis. Kondisi hiperkalemia jarang terjadi kecuali pada stadium akhir penyakit ginjal kronis yang biasanya disertai dengan oligouria atau anuria (Price dkk., 2006 ). Studi retrospektif menunjukkan hipokalemia terjadi pada $20-30 \%$ kucing penderita penyakit ginjal kronis (Lulich dkk., 1992). Banyak bentuk suplemen kalium tersedia seperti serbuk yang dicampur dengan pakan, tablet kunyah maupun non - kunyah dan bentuk gel (Wolf, 2015). Selain diet dengan penambahan K, pemberian Kalium glukonat dan kalium sitrat per oral serta kalium klorida parenteral sering digunakan untuk koreksi hipokalemia pada anjing dan kucing (Ross, 2008). Dosis kalium sitrat per oral untuk kucing adalah $50-75 \mathrm{mg} / \mathrm{kg}$ PO setiap 12 jam (Polzin dkk., 2005). Suplementasi dengan kalium glukonat atau kalium sitrat dianjurkan jika serum $\mathrm{K}<3,5 \mathrm{mmol}$ / $1(<3,5 \mathrm{mEq} / 1)$, dengan dosis awal 1-4 mmol (1-4 $\mathrm{mEq}) \mathrm{K}$ setiap 12 jam, disesuaikan dengan respon dari kucing (Sparkes dkk., 2016).

\section{Kontrol Proteinuria}

Proteinuria adalah manifestasi utama pada penyakit ginjal dan merupakan indikator turunnya fungsi ginjal. Proteinuria merupakan gejala utama pada sindrom nefrotik. Perubahan hemodinamik yang dialami nefron berupa peningkatan aliran darah glomerulus dan tekanan intrakapiler glomerulus menyebabkan meningkatnya protein dalam filtrat glomerulus. Meningkatnya jumlah protein yang difiltrasi oleh glomerulus juga disebabkan oleh meningkatnya permeabilitas kapiler glomerulus (Schlondorff, 2008). Protein dalam filtrat glomerulus akan direabsorbsi oleh sel epitel tubulus proksimal, kemudian mengalami proses endositosis, selanjutnya mengalami degradasi oleh lisosom menjadi asamasam amino (Keane, 2000). Bila nefron mengalami kerusakan maka akan terjadi penurunan laju filtrasi glomeruli yang mana ginjal mengalami gangguan dalam fungsi eksresi dan fungsi non-eksresi sehingga dapat melanjut menjadi penyakit ginjal kronis (Ruggenenti dkk., 2012). Beberapa metode deteksi dapat digunakan untuk mengevaluasi kejadian proteinuria pada anjing dan kucing seperti analisa urin konvensional, penentuan rasio protein urin: kreatinin 
(UP/C), pemeriksaan konsentrasi albumin urin (Lees dkk., 2005; Bacic dkk., 2010), N-konsentrasi acetyl- $\beta$-d-glucos-aminidase (Jepson dkk., 2010), retinol binding protein (Smets dkk., 2010) Beratnya proteinuria memiliki korelasi dengan perkembangan penyakit ginjal baik pada manusia, anjing maupun kucing (Jacob dkk., 2005; Nabity dkk., 2007).

Saat ini, rasio protein urin: kreatinin (UPC) merupakan gold standard untuk uji proteinuria pada anjing maupun kucing. Pengujian tunggal sampel urin yang diambil dengan waktu acak memiliki korelasi kuat dengan jumlah protein urin selama 24 jam (Monroe dkk., 1989). Menurut Jacob dkk. (2005), anjing dengan diagnosa awal CKD disertai azotemia dan nilai UPC $>1,0$ akan mengalami kematian lebih cepat dibandingkan anjing penderita CKD dengan nilai $\mathrm{UPC}<1,0$. Pada anjing, nilai $\mathrm{UPC} \geq 0,5$ yang berasal dari 3 sampel selama 2 minggu pemeriksaan merupakan bukti kuat dari persisten proteinuria akibat kerusakan ginjal (Center dkk., 1985). Pada kucing, nilai UPC $\geq 1,0$ menunjukkan kecurigaan adanya kerusakan pada glomerulus. Sedangkan hasil penelitian Syme dkk. (2006) menunjukkan bahwa nilai UPC antara $0,5-1,2$ baru memiliki kaitan klinis dengan penyakit ginjal kronis. Sedangkan nilai UPC 1,0 sampai 2 kadang kadang menunjukkan stadium akhir penyakit ginjal kronis pada kucing (Lees dkk., 2005). Semakin rendah nilai UPC maka semakin baik prognosanya (Walker dkk., 2004).

Hasil studi terbaru menunjukkan bahwa pada anjing dan kucing, seperti pada manusia, proteinuria persisten terkait dengan tingginya frekuensi penyakit ginjal kronis (Jacob dkk., 2005). Derajat proteinuria dapat menjadi indeks diagnostik untuk anjing dan kucing penderita penyakit ginjal kronis (Elliott dkk., 2000). Pengobatan dengan ACEi seperti elanapril, benazapril dan lisinopril pada manusia maupun hewan percobaan mampu menurunkan kejadian proteinuria dan mengurangi laju kerusakan ginjal (Lees dkk., 2004). Hasil studi juga menunjukkan bahwa status proteinuria anjing dan kucing yang diterapi dengan ACEi akan terkoreksi (Grodecki dkk., 1997). Hasil pengobatan elanapril pada anjing penderita penyakit ginjal kronis dengan status proteinuria ringan menunjukkan penurunan kadar protein dan menekan laju kerusakan ginjal (Brown dkk., 2003). Dosis elanapril per oral yang dianjurkan untuk kucing adalah 0,25 sampai $0,5 \mathrm{mg} / \mathrm{kg}$ BB, setiap $12-24$ jam. Sedangkan untuk anjing dosis per oral adalah 0,5 mg/kg BB, PO setiap 12 - 24 jam (Plumb, 2011). Menurut Mizutani (2006) pemberian benazepril 0,5-1 $\mathrm{mg} / \mathrm{kg}$ benazepril sehari sekali selama 6 bulan secara konsisten mengurangi kejadian proteinuria pada berbagai stadium penyakit ginjal kronis pada kucing.

\section{Manajemen Diet}

Pakan penyakit ginjal kronis

Rasa pakan komersial untuk penyakit ginjal kronis pada umumnya memiliki palatabilitas yang rendah jika dibandingkan dengan pakan normal dan kemungkinan disebabkan karena rendahnya kandungan protein, $\mathrm{P}$ dan $\mathrm{Na}$ tetapi tinggi serat terlarut, kapasitas asam basa, vitamin B kompleks, antioksidan dan asam lemak omega-3. Hal tersebut dapat mengakibatkan rendahnya asupan pakan dan akan memperburuk kondisi hewan (Allen dkk., 2000; Markovich dkk., 2015). Perubahan dari pakan harian ke pakan untuk penyakit ginjal kronis pada kucing harus dilakukan secara bertahap dan membutuhkan waktu paling tidak selama 7 hari. Namun ada perkecualian dimana beberapa kucing membutuhkan waktu 3 sampai 4 minggu (Roudebush dkk., 2009).

Pakan komersial khusus penyakit ginjal untuk anjing penderita penyakit ginjal kronis pada 
umumnya mengandung protein terbatas. Pakan dengan kandungan protein rendah (8\% dan 17\%) mampu menurunkan kadar BUN dan tingkat kematian pada anjing penderita penyakit ginjal kronis (Polzin dkk., 1984). Dalam sebuah penelitian, diperlukan waktu sampai 4 minggu untuk memperoleh nilai UPC normal pada anjing yang diberi diet komersial khusus penyakit ginjal (Lees, 2005). Penelitian Jacob dkk. (2002) menunjukkan bahwa anjing penderita penyakit ginjal kronis yang diberi pakan komersial khusus penyakit ginjal selama 2 tahun menjadi lebih lambat kerusakan ginjalnya dibandingkan dengan anjing penderita yang diberi pakan normal.

Pakan komersial khusus penyakit ginjal pada kucing biasanya mengandung 6-7 g protein per 100 kkal (di atas $5 \mathrm{~g} / 100 \mathrm{kkal}$ direkomendasikan untuk kucing dewasa) (NRC, 2006). Kebutuhan energi untuk kucing berumur diatas 13 tahun kemungkinan akan meningkat sehingga pembatasan protein dapat menyebabkan hilangnya jaringan tubuh (Laflamme dan Hannah, 2013), sehingga dianjurkan diet dengan protein terbatas moderat disertai dengan pengamatan massa tubuh, berat badan dan asupan kalori. Pakan komersial khusus penyakit ginjal pada kucing biasanya kandungan P juga rendah jika dibandingkan dengan pakan normal (Kidder dan Chew, 2009). Pembatasan diet protein sekitar 2,7 g / kg / hari dan asupan energi sekitar $56 \mathrm{kkal} /$ hari mengakibatkan lesi ginjal lebih sedikit pada kucing penderita gagal ginjal dibandingkan dengan konsumsi sekitar 6,8 $\mathrm{g}$ protein / kg / hari dan 75 kkal / hari (Adam dkk., 1993).

Penelitian suplementasi antioksidan pada terapi penyakit ginjal kronis menunjukkan hasil yang bervariasi. Suplementasi vitamin E (alfa- tokoferol) pada kucing pada kucing penderita penyakit ginjal kronis mungkin memiliki efek positif dalam memperbaiki kondisi anemia (Bargnoux dkk., 2013). Namun demikian hasil tersebut berbeda dengan hasil penelitian yang dilakukan oleh Timmons dan Webb (2016). Pemberian suplemen vitamin E dengan dosis 30 IU/hari selama 3 bulan tidak mampu memperbaiki kondisi anemia secara signifikan. Hasil penelitian Yu dan Robinson (2006) menunjukkan bahwa kombinasi antara vitamin E, C dan beta - karoten mampu mengatasi oksidatif stress sehingga akan memperbaiki kondisi anemia.

Manfaat asam lemak omega-3 minyak ikan telah banyak diteliti dan direkomendasikan dalam pengelolaan berbagai macam penyakit termasuk penyakit ginjal kronis (Lenox dan Bauer, 2013). Penelitian yang dilakukan oleh Brown dkk. (1998) menunjukkan bahwa suplementasi pakan dengan asam lemak tidak jenuh majemuk dan antioksidan dapat memberikan efek protektif pada hewan penderita penyakit ginjal kronis. Selanjutnya Brown dkk. (2000) menyatakan bahwa efek protektif asam lemak omega-3 kemungkinan melalui penurunan produksi prostaglandin dan penurunan tekanan kapiler glomerulus. Rentang dosis asam lemak omega-3 yang dianjurkan adalah 10-200 mg/kg PO 124 hari. Forrester dkk. (2010) menganjurkan pakan dengan tambahan asam lemak omega - 3 0,4\% sampai 2,5\% dari bahan kering untuk anjing penderita penyakit ginjal kronis. Studi retrospektif terhadap kelangsungan hidup dari 146 kucing penderita penyakit ginjal kronis yang diberi pakan normal dan pakan komersial khusus penyakit ginjal menunjukkan bahwa kelangsungan hidup lebih panjang pada kucing dengan pakan komersial khusus penyakit ginjal. Kelangsungan hidup yang panjang tersebut terkait dengan pakan yang mengandung Eicosapentaenoic acid (EPA) tinggi (Plantinga dkk., 2005). 


\section{Kesimpulan}

Berbagai macam strategi pengobatan dan diet dapat digunakan untuk mengelola baik anjing maupun kucing penderita penyakit ginjal kronis. Penyakit ginjal kronis tidak dapat disembuhkan sehingga pengelolaan pengobatan dan diet yang tepat lebih ditujukan untuk memperbaiki kualitas hidup dan memperpanjang hidup hewan.

\section{Daftar Pustaka}

Adams, L. G. (2004). Chronic renal failure. In: The 5- Minute Veterinary Consult. 4th edn. Eds L. P. Tilley and F. W. K. Smith. Lippincott William \& Wilkins, Philadelphia, PA, USA. : 1124-1125.

Adams, L.G. (2013). How I treat anorexia in cats with chronic kidney disease. Proc World Small Animal Veterinary Assoc Congress Proc.

Allen, T. A., Polzin, D. J. and Adams, L. G. (2000). Renal disease. In: Small Animal Clinical Nutrition. 4th edn. Eds M. S. Hand, C. D. Thatcher, R. L. Remillard and P. Roudebush. Mark Morris Institute, Topeka, KS, USA. : 563-598.

Arora, P. (2014). Chronic Kidney Disease. MedScape. Diakses dari http://emedicine.medscape.com/ article/238798-overview. Pada tanggal 18 Agustus 2016.

Arzi, B., Anderson, J.G. and Verstraete, F.J.M. (2008). Oral manifestations of systemic disorders in dogs and cats. Journal of Veterinary Clinical Science 1 : 112-124.

Atlas, S.A. (2007). The renin-angiotensin aldosterone system: Pathophysiological role and pharmacologic inhibition. Journal of Managed Care Pharmacy. 13: 9-20.

Bacic, A., Kogika, M.M., Barbaro, K.C., Iuamoto, C.S., Simoes, D.M. and Santoro, M.L. (2010). Evaluation of albuminuria and its relationship with blood pressure in dogs with chronic kidney disease. Veterinary Clinical Pathology 39 : 203-209.

Barber, P.J. and Elliott, J. (1998) Feline chronic renal failure: calcium homeostasis in 80 cases diagnosed between 1992 and 1995. J Small Anim Pract. 39 : 108-116.

Barber, P.J., Rawlings, J.M., Markwell, P.J. and Elliott, J. (1999). Effect of dietary phosphate restriction on renal secondary hyperparathyroidism in the cat. J Small Anim Pract. 40:62-70.

Bargnoux, A., Cristol, J., Jaussent, I., Chalabi, L., Bories, P., Dion, J.J., Henri, P., Delage, M., Dupuy, A.M., Badiou, S., Canaud, B. and Morena, M. (2013). Vitamin E-coated polysulfone membrane improved red blood cell antioxidant status in hemodialysis patients. Nephrology 26 :556-563.

Bartges, J.W. (2012). Chronic Kidney Disease in Dogs and Cats. Veterinary Clinics of North America: Small Animal Practice 2012;42:669692. Bartges JW. Chronic Kidney Disease in Dogs and Cats. Veterinary Clinics of North America: Small Animal Practice. 42 :669-692.

Bartlett, P. C., Van Buren, J.W., . Bartlett, A. D. and, Chu.Z (2010). Research Article CaseControl Study of Risk Factors Associated with Feline and Canine Chronic Kidney Disease. Veterinary Medicine International Vol.2010, Article ID 957570, 1 - 9.

Bellasi, A., Kooienga, L. and Block, G.A. (2006). Phosphate binders: new products and challenges. Hemodial Int. 10: 225-34.

Bernachon, N., Fournel, S., Gatto, H., Monginoux, P. and McGahie, D. (2014). Effect of a Product Containing the Dietary Phosphate Binders Calcium and Magnesium Carbonate Associated with Other Reno-protectant Substances (Pronefra ${ }^{\circledR}$ ) on Blood Parameters and Mineral Balance in Adult Cats. Intern $J$ Appl Res Vet Med. Vol. 12 (1) : 8 - 17.

Bernsteen, L., Gregory, C.R., Aronson, L.R., Lirtzman, R.A. and Brummer, D.G. (1999). Acute toxoplasmosis following renal transplantation in three cats and a dog. Journal of the American Veterinary Medical Association 215(8):1123-1126. 
Bloomberg, R.M., Pook, H. A., Jacobs, R. M. and Van Gorder, J. M. (1992). Human recombinant eritropoetin therapy in a cat with chronic renal failure. Can Vet $J$ Vol. $33: 612$ - 613 .

Bodey, A.R. and Michell, A.R. (1996). Epidemiological study of blood pressure in domestic dogs. J Small Anim Pract. 37 :116-125.

Brody, T. (1999). Nutritional Biochemistry. 2nd edn. Academic Press, San Diego, CA, USA. : 575.

Brown, S.A. (2015). Renal dysfunction in small animals. The Merck Veterinary Manual website. www. merckmanuals.com/vet/urinary_system/ noninfectious_diseases_of_the_urinary_ system_in_small_animals/renal_dysfunction in_small_animals. html.. Diakses Januari 14.

Brown, S.A. and Finco, D.R. (1995). Reassessment of the use of calcitriol in chronic renal failure. In: Bonagura JD, ed. Kirk's Current Veterinary Therapy XII. Philadelphia: WB Saunders : 963-966.

Brown, S.A., Atkins, B.C., Carr, R., Cowgill, A., Davidson, L., Egner, M., Elliott, B., Henik J., Labato, R., Littman, M., Polzin, M., Ross, D., Snyder, L.P. and Stepien, R. (2007). "Guidelines for the identification, evaluation, and management of systemic hypertension in dogs and cats," J Vet Intern Med. 21 :542-558.

Brown, S.A., Finco, D.R., Bartges, J.W., Brown, C.A. and Barsanti, J.A. (1998). Interventional nutrition for renal disease. Clin Tech Small Anim Pract. 13: 217-223.

Brown, S.A., Brown, C.A., Crowell, W.A., Barsanti, J.A., Kang, C.W., Allen, T., Cowell, C. and Finco, D.R. (2000) Effects of dietary polyunsaturated fatty acid supplementation in early renal insufficiency in dogs. J Lab Clin Med.135:275-286.

Brown, S.A., Finco, D.R., Brown, C.A., Crowell, W.A., Alva, R., Ericsson, G.E. and Cooper, T. (2003). Evaluation of the effects of inhibition of angiotensin converting enzyme with enalapril in dogs with induced chronic renal insufficiency. Am J Vet Res. 64: 321-327.

Brown, S.A., Brown, C.A., Crowell, W.A., Basanti,
J.A. and Finco D.R. (1996). Does modifying dietary lipids influence the progression of renal failure? Vet Clin North Am. 26:1277-1285.

Burkholder, W.J. (2000). Dietary considerations for dogs and cats with renal disease. Journal of the American Veterinary Medical Association 216 : 1730-1734.

Car, B.D. (2001). Erythropoiesis and erythrokinetics. In: Feldman BF, Zinkl JG, Jain NC, eds. Schalm's Veterinary Hematology New York: McGraw-Hill,:271-288.

Center, S.A., Wilkinson, E., Smith, C.A., Erb, H. and Lewis, R.M. (1985). 24-Hour urine protein/creatinine ratio in dogs with protein-losing nephropathies. J Am Vet Med Assoc. 187:820-824.

Chakrabarti, S., Syme, H.M. and Elliott, J. (2012). Clinicopathological variables predicting progression of azotemia in cats with chronic kidney disease. J Vet Intern Med. 26: 275-281.

Chalhoub, S., Langston, C.E. and Eatroff, A. (2011). Anemia Of Renal Disease What it is, what to do and what's new. Journal of Feline Medicine and Surgery $13: 629-640$.

Chalhoub, S., Langston, C.E. and Farrelly, J. (2012). The use of darbepoetin to stimulate erythropoiesis in anemia of chronic kidney disease in cats: 25 cases. $J$ Vet Intern Med. 26(2) :363-369.

Chandler, M.L., Elwood. C., Murphy, K.F., Gajanayake, I. and Syme, H.M. (2007). Juvenile nephropathy in 37 boxer dogs. $J$ Small Anim Pract. 48(12):690-694.

Chen, W. and Abramowitz, M. K. (2014). Metabolic acidosis and the progression of chronic kidney disease. BMC Nephrology 15 : 55.

Chen, W. and Abramowitz, M. K (2014). Treatment of Metabolic Acidosis in Patients With CKD Am J Kidney Dis. Feb; 63(2): 311-317.

Chew, D.J. (2015). Chronic Kidney Disease (CKD) in Dogs \& Cats - Staging and Management Strategies. A Presentation to the Virginia Veterinary Medical Association. Virginia Veterinary Conference. : $1-22$ 
Chew, D.J. and Nagode, L.A. (1992). Kalsitriol in the treatment of chronic renal failure. In: Kirk BW, Bonagura JD, eds. Current Veterinary Therapy XI, Small Animal Practice. Philadelphia: WB Saunders. :857-860.

Cook, S. M. and Lothrop, C. D. (1994). Serum eritropoetin concentrations measured by radioimmunoassay in normal, polycythemic, and anemic dogs and cats. $J$ Vet Intern Med. $8: 18-25$.

Cortadellas, O., del Palacio, M.J., Bayón, A., Albert, A. and Talavera, $J$. (2006). Systemic hypertension in dogs with leishmaniasis: Prevalence and clinical consequences. J Vet Int Med. 20: 941-947.

Cowgill, L. D. (1991). Eritropoetin: Its use in the treatment of chronic renal failure in dogs and cats. Proc Annu Waltham/OSU Symp Treat Small Anim Dis;15:65-71.

Cowgill, L.D., James, K.M., Levy, J.K., Browne, J.K., Miller, A., Lobingier, R.T. and Egrie, J.C. (1998). Use of recombinant human eritropoetin for management of anemia in dogs and cats with renal failure. J Am Vet Med Assoc. 212: 521-8.

Crisp, M.S., Chew, D. J., DiBartola, S. P. and Birchard, S.J. (1989). "Peritoneal Dialysis inDogs and Cats: 27 Cases" (1976-1987). J. Am. Vet. Med. Assoc. 195: 1262-1266.

de Brito-Ashurst, I., Varagunam, M., Raftery, M.J. and Yaqoob, M.M. (2009). Bicarbonate supplementation slows progression of CKD and improves nutritional status. $J$ Am Soc Nephrol. 20: 2075-2084.

de Morais, H.A., Bach, J.F. and diBartola, S.P. (2008). Metabolic acidbase disorders in the critical care unit. Vet Clin North Am Small Anim Pract. 38: 559-574.

DiBartola, S.P. and de Morais, H.A. (2006). Disorders of potassium: Hypokalemia and hyperkalemia, in DiBartola SP (ed): Fluid, Electrolyte, and Acid-Base Disorders. 3rd ed., Philadelphia, Elsevier : 91-121.

Dibartola, S.P., and Willard, M.D. (2006). Disorders of phosphorous: hypophosphatemia and hyperphosphatemia. In: Dibartola SP, ed.
Fluid, electrolyte, and acid-base disorders in small animal practice. 3rd edn. Missouri: Elsevier. : 195-209.

Dokuzeylul, B. And Kayar, M.E. A. (2016). Prevalence of systemic disorders in cats with oral lesions. Veterinarni Medicina, 61 (4) : 219-223.

Dow, S.W., Fettman, M.J., LeCouteur, R.A. and Hamar, D.W. (1987). Potassium depletion in cats: Renal and dietary influences. $J$ Am Vet Med Assoc;191:1569-1575.

Dzanis,D.A.,Corbellini,C.N.,Krook,L.andKallfelz,F.A. (1991). Effects of 1,25- dihydroxycholecalciferol and 24,25-dihydroxycholecalciferol in dogs with impaired renal function. $J$ Nutr. 121(11 Suppl) : S70-S72.

Elliott, J. (2008). Hyperphosphataemia And CKD .http://www.vettimes.co.uk. : $1-19$.

Elliott, J. and Barber, P.J. (1998). Feline chronic renal failure: clinical findings in 80 cases diagnosed between 1992 and 1995. J Small Anim Pract. $39: 78-85$.

Elliott, J., Rawlings, J.M., Markwell, P.J. and Barber, P.J. (2000). Survival of cats with naturally occurring chronic renal failure: effect of dietary management. J Small Anim Pract 41(6): $235-242$.

Elliott, J., Syme, H.M., Reubens, E. and Markwell, P.J. (2003). Assessment of acid-base status of cats with naturally occurring chronic renal failure. J Small Anim Pract. 44: 65-70.

Erslev, A.J. and Besarab, A. (1997). Eritropoetin in the pathogenesis and treatment of the anemia of chronic renal failure. Kidney Int 51 : 622-630.

Ettinger, S.J. and Feldman, E.C. (2005). Textbook of Veterinary Internal Medicine Volume II, VI ed. St.Louis: Elsvier Saunders. 622-630.

Ettinger, S.J., Benitz, A.M., Ericsson, G.F., Cifelli, S., Jernigan, A.D., Longhofer, S.L., Trimboli, W. and Hanson, P.D. (1998). Effects of enalapril maleate on survival of dogs with naturally acquired heart failure. The Long-Term Investigation of Veterinary Enalapril (LIVE) Study Group. $J$ Am Vet Med Assoc. 213 : 1573-1577. 
Finch, N.C., Syme, H.M. and Elliott J. (2016). Risk Factors for Development of Chronic Kidney Disease in Cats. J Vet Intern Med ;30:602-610.

Forrester, D.S., Adams, L.G. and Allen, T.A. (2010). Chronic kidney disease. In: Hand MS, Thatcher CD, Remillard RL, et al, eds. Small animal clinical nutrition, 5th ed. Topeka, Kan: Mark Morris Institute. : 765-800.

Geddes, R.F., Elliott, J. and Syme, H.M. (2015). Relationship between plasma fibroblast growth factor-23 concentration and survival time in cats with chronic kidney disease. $J$ Vet Intern Med. 29: 1494-1501.

Grauer, G.F. (2005). Early detection of renal damage and disease in dogs and cats. Vet Clin North Am Small Anim Pract 35 :581-596.

Grodecki, K.M., Gains, M.J., Baumal, R., Osmond, D.H., Cotter, B., Valli, V.E. and Jacobs, R.M. (1997). Treatment of X-linked hereditary nephritis in Samoyed dogs with angiotensin converting enzyme (ACE) inhibitor. J Comp Pathol. 117 :209-225.

Hall, J.A., Yerramilli, M., Obare, E., Yu, S. and Jewell, D.E. (2014). Comparison of serum concentrations of symmetric dimethylarginine and creatinine as kidney function biomarkers in healthy geriatric cats fed reduced protein foods enriched with fish oil, L-carnitine, and medium-chain triglycerides. Vet J. 202(3):588-596.

Hostutler, R.A., DiBartola, S.P., Chew, D.J., Nagode, L.A., Schenck, P.A., Rajala-Schultz, P.J. and Drost, W.T. (2006). Comparison of the effects of daily and intermittent-dose kalsitriol on serum parathyroid hormone and ionized calcium concentrations in normal cats and cats with chronic renal failure. $J$ Vet Intern Med. 20(6) :1307-1313.

Houston, D. M. (2016). Chronic Kidney Disease (CKD) in Dogs \& Cats: An update 2016. centredmv.com/ wp.../2016/.../Notes-conférences-Dre-Houston. : 10

Jacob, F., Polzin, D.J., Osborne, C.A., Neaton, J.D., Kirk, C.A. and Allen, T.A., (2005). Evaluation of the association between initial proteinuria and morbidity rate or death in dogs with naturally occurring chronic renal failure. $J \mathrm{Am}$
Vet Med Assoc. $226: 393-400$.

Jepson, R. E., Elliott, J. Brodbelt, D. and Syme, H. M. (2007). "Effect of control of systolic blood pressure on survival in cats with systemic hypertension," Journal of Veterinary Internal Medicine, vol. 21, no. 3 : 402-409.

Jepson, R.E., Vallance, C., Syme, H.M. and Elliott, J. (2010). Assessment of urinary N-acetyl-betaD-glucosaminidase activity in geriatric cats with variable plasma creatinine concentrations with and without azotemia. American Journal of Veterinary Research $71:$ 241-247.

Jones, B.R., Gething, M.A., Badcoe, L.M., Pauli, J.V. and Davies, E. (1989). Familial progressive nephropathy in young Bull Terriers. $N Z$ Vet $J$. 37(2):79-82.

Kaplan, M.A., Canterbury, J.W., Gavellas, G., Jaffe, D., Bourgoinnie, J.J., Reiss, E. and Bricker N.S. (1978). The calcemie and phosphaturic effects of parathyroid hormone in normal and uremic dog. Metabolism, 27 : 1785-1792.

Keane, W.F. (2000). Proteinuria: Its clinical importance and role in progressive renal disease. $\mathrm{Am} J$ Kidney Dis. 35(Suppl 1) :S97-S105.

Kidder, A. and Chew, D. (2009). "Treatment options for hyperphosphatemia in feline CKD: what's out there?" J Feline Med Surg., vol. 11, no. 11: 913-924.

Kimmel, P.L. and Rosenberg, M.E. (2014). Chronic Renal Disease, Academic Press, San Diego CA:310-319.

King, J. N., Gunn-Moore, D. A., Tasker, S., Gleadhill, A. and Strehlau. G. (2006). Tolerability and efficacy of benazepril in cats with chronic kidney disease. Journal of Veterinary Internal Medicine 20(5) : 1054-1064.

Kralova, S., Leva, L. and Toman, M. (2009). Polymorphonuclear function in naturally occurring renal failure in dogs. Veterinarni Medicina 54 (5) : 236-243.

Laflamme, D.P. and Hannah, S.S. (2013). Discrepancy between use of lean body mass or nitrogen balance to determine protein requirements for adult cats. J Feline Med Surg. 15: 691-697. 
Langston, C.E. (2009) Fluid treatment for renal failure (Proceedings) www. veterinarycalendar. dvm360.com/fluid-treatment-renal-failure-. : 1 -4. Diakses tanggal 9 Juni 2016.

Lawson, J., Elliott, J., Wheeler-Jones, C., Syme, H, and Jepson, R. (2015). Review Renal fibrosis in feline chronic kidney disease: Known mediators and mechanisms of injury. The Veterinary Journal 203 :18-26.

Lees, G.E., Helman, R.G., Homco, L.D., Millichamp, N.J., Hunter, J.F. and Frey M.S. (1998). Early diagnosis of familial nephropathy in English cocker spaniels. Journal of the American Animal Hospital Association: Vol. 34, No. 3, pp. 189-195.

Lees, G.E., Brown, S.A., Elliott, J., Grauer, G.E. and Vaden, S.L. (2005). Assessment and management of proteinuria in dogs and cats: 2004 ACVIM Forum Consensus Statement (small animal). $J$ Vet Intern Med. 19 (3) :377-385.

Lenox, C. E. and Bauer, J.E. (2013). Potential Adverse Effects of Omega-3 Fatty Acids in Dogs and Cats. Review. J Vet Intern Med 27 :217-226.

Littman, M.P. (1994). Spontaneous Systemic Hypertension in 24 Cats. J Vet Intern Med. 8:79-86.

López-Sendón, J., Swedberg, K., McMurray, J., Tamargo, J., Maggioni, A.P., Dargie, H., Tendera, M., Waagstein, F., Kjekshus, J., Lechat, P. and TorpPedersen, C. (2004). Expert consensus document on angiotensin converting enzyme inhibitors in cardiovascular disease. The Task Force on ACE-inhibitors of the European Society of Cardiology. Eur Heart J. 25 :1454-1470.

MacLeod, J.N., Tetreault, J.W., Lorschy, K.S. and Gu, D.N. (1998). Expression and bioactivity of recombinant canine eritropoetin. Am J Vet Res 59: 1144-1148.

Maddison, J. and Syme, H. (2010). Chronic kidney disease in dogs and cats II: Principles of management continue education Irish Veterinary Journal Vol. 63 No. 2 : 106 - 109.

Maiese, K., Chong, Z.Z. and Shang, Y.C. (2008). Raves and risks for eritropoetin. Cytokine Growth Factor Rev. 19 :145-155.
Markovich, J. E., Freeman, L. M., Labato, M. A. and Cailin, R. (2015). Survey of dietary and medication practices of owners of cats with chronic kidney disease. J Feline Med Surg; 17: 979-983.

Marx, S.J. (2000). Hyperparathyroid and hypoparathyroid disorders. N Engl J Med 343(25) :1863-1875.

McLeland, S.M., Lunn, K.F., Duncan, C.G., Refsal, K.R. and Quimby, J.M. (2014). Relationship among serum creatinine, serum gastrin, calcium-phosphorus product, and uremic gastropathy in cats with chronic kidney disease. J. Vet. Intern. Med. 28: 827-837.

Mitani, S., Yabuki, A., Taniguchi, K. And Yamato, O. (2013). Association between the intrarenal renin-angiotensin system and renal injury in chronic kidney disease of dogs and cats. $J$ Vet Med Sci. 75 :127-133.

Mizutani, H., Koyama, H., Watanabe, T., Kitagawa, H., Nakano, M., Kajiwara, K. and. King, J. N. (2006). Evaluation of the Clinical Efficacy of Benazepril in the Treatment of Chronic Renal Insufficiency in Cats. J Vet Intern Med 20 :1074-1079.

Monroe, W.E., Davenport, D.J. and Saunders G.K. (1989). Twenty-four hour urinary protein loss in healthy cats and the urinary proteincreatinine ratio as an estimate. Am J Vet Res.50 :1906-1909.

Morar, D., Falcă, C., Moł, T., Cristina, P., Ciulan, V. and Simiz, F. (2010). Blood Pressure In Cats With Chronic Renal Failure. Lucrări Stiintifice Medicină Veterinară Vol. Xliii (1) Timisoara. : $319-324$.

Morar, D., Falcă, C., Moł, T., Cristina, P., Galbenu, P L. and Ciulan, V. (2009). Effect Of Amlodipine On Blood Pressure In Cats With Chronic Renal Failure. Lucrări Stiintifice Medicină Veterinară Vol. XLII (2), Timisoara. : $231-235$

Morgan, R.V. (1986) Systemic hypertension in four cats: ocular and medical findings. J Am Anim Hosp Assoc. 22 :615-621.

Nabity, M. B. Boggess, M. M., Kashtan, C. E. and. Lees, G. E. (2007). Day-to-Day Variation of 
the Urine Protein : Creatinine Ratio in Female Dogs with Stable Glomerular Proteinuria Caused by X-Linked Hereditary Nephropathy. $J$ Vet Intern Med. 21 :425-430.

National Research Council. Nutrient requirements of dogs and cats. Washington, DC: National Academies Press, 2006. DOI: 10.17226/10668.

Neel, J.A. and Grindem, C.B. (2000). Understanding and evaluating renal function. Vet Med. :555566.

Nelson, R.W. and Couto, C.G. (2009). Small animal internal medicine, 4th ed. ed. Edinburgh: Mosby. : $653-660$.

Nelson,R.W.andFeldman,E.C.(2004).Hypercalcemia and primary hyperparathyroidism. In: Feldman EC, Nelson RW, eds. Canine and Feline Endocrinology and Reproduction. 3rd ed. St. Louis: WB Saunders; :659-715.

O’Neill, D. G., Elliott, J., Church, D.B., McGreevy, P.D., Thomson, P.C. and Brodbelt, D.C. (2013). Chronic kidney disease in dogs in UK veterinary practices: prevalence, risk factors, and survival. $J$ Vet Intern Med.;27(4):814-821.

Plumb, D.C. (2011). Veterinary Drug Handbook. 7th ed. Wiley-Blackwell, Ames, Iowa, USA. 1567.

Polzin, D. J. and Osborne, C.A. (1995). Pathophysiology of renal failure and uremia. In Canine and Feline Nephrology and Urology. Eds C. A. Osborne, D. R. Finco. Philadelphia,Williams \& Wilkins. :335-367.

Polzin, D., Ross, S. and Osborne, C. (2005). Clinical benefit of kalsitriol in canine chronic kidney disease. Journal of Veterinary Internal Medicine 19: 433 - 437.

Polzin, D.J. (2011) Chronic Kidney Disease in Small Animals. Veterinary Clinics of North America: Small Animal Practice 41:15-30.

Polzin, D.J., Osborne, C.A. and Ross S. (2010). Chronic Kidney Disease. In: Ettinger SJ, Feldman EC, eds. Textbook of Veterinary Internal Medicine, 7th ed. St. Louis: Elsevier Saunders. : 1900-2021.
Polzin, D.J., Osborne, C.A. and Ross, S. (2005). Chronic kidney disease, in SJ Ettinger, Feldman EC (eds): Textbook of Veterinary Internal Medicine, ed 6. Philadelphia, WB Saunders. : 1756-1785.

Polzin, D.J., Osborne, C.A. and Ross, S. (2005). Chronic Kidney Disease. In: Ettinger SJ, Feldman EC, eds. Textbook of veterinary internal medicine : diseases of the dog and cat, 6th ed. / Stephen J. Ettinger, Edward C. Feldman. ed. St. Louis, Miss. ; Oxford: Elsevier Saunder :1756-1785.

Polzin, D.J., Osborne, C.A., Hayden, D.W. and Stevens, J.B. (1984). Influence of modified protein diets on morbidity, mortality, and renal function in dogs with induced chronic renal failure. Am J Vet Res. 45 :506- 517.

Polzin, D.J., Ross, S. and Osborne, C.A. (2009). Kalsitriol. In: Bonagura J.D. \& Twedt D.C. (Eds), Kirk's Current Veterinary Therapy. XIV. Saunders Elsevier, St Louis, Missouri. : 892-895.

Powell, L.L. (2014). Top 5 Indications For Fluid Therapy. www.veterinaryteambrief.com. : 10 - 12. Diakses tanggal 9 Juni 2016

Price, S. A. and Wilson, L. M. (2005). Patofisiologi: konsep klinis proses-proses penyakit (6 ed.). Jakarta: EGC.

Quimby, J. and Lappin, M. (2016). Evaluating Sucralfate as a Phosphate Binder in Normal Cats and Cats with Chronic Kidney Disease. $J$ Am Anim Hosp Assoc. 52(1) :8-12.

Randolph, J. E., Scarlett, J., Stokol, T. and Macleod, J. N. (2004). Clinical efficacy and safety of recombinant canine eritropoetin in dogs with anemia of chronic renal failure and dogs with recombinant human eritropoetin-induced red cell aplasia. J Vet Intern Med 18 : 81-91.

Randolph, J.E., Scarlett, J.M., Stokol, T., Saunders, K.M. MacLeod, J.N. (2004). Expression, bioactivity, and clinical assessment of recombinant feline eritropoetin. Am J Vet Res 65: 1355-1366.

Reynolds, B.S.and Lefebvre, H.P. (2013). Feline CKD: Pathophysiology and risk factors - What 
do we know? Journal of Feline Medicine and Surgery 15 (Suppl. 1), 3-14.

Ross, S. (2008). Diagnosis and Management of Chronic Kidney Disease in Dogs and Cats Proceedings, The 15th Congress of FAVA FAVA -OIE Joint Symposium on Emerging Diseases Bangkok, Thailand : S89-S93.

Roudebush, P., Polzin, D. J., Adams, L. G., Towell, T. L. and Forrester, S. D. (2010). REVIEW. An evidence based review of therapies for canine chronic kidney disease. Journal of Small Animal Practice $51: 244-252$.

Roudebush, P., Polzin, D. J., Ross, S. J., Towell, T. L., Adams, L. G. and Forrester, S. D. (2009). Therapies for feline chronic kidney disease. What is the evidence? Journal of Feline Medicine \& Surgery $11:$ 195-210.

Ruggenenti, P., Cravedi, P. and Remuzzi, G. (2012). Mechanisms and treatment of CKD. J Am Soc Nephrol. 23: 1917-1928.

Savica, V., Calò, L. A., Monardo, P., Davis, P. A., Granata, A., Santoro, D., Savica, R., Musolino, R., Comelli, M. C. and Bellinghieri, G. (2009). "'Salivary phosphate- ' binding chewing gum reduces hyperphosphatemia in dialysis patients," Journal of the American Society of Nephrology, vol. 20, no. 3: 639-644.

Schlondorff, D.O. (2008). Overview of factors contributing to the pathophysiology of progressive renal disease. Kidney Int. 74: 860866.

Schoolwerth, A.C., Kaneko, T.M., Sedlacek, M., Block, C.A. and Remillard, B.D. (2006). Acidbase disturbances in the intensive care unit: metabolic acidosis. Semin Dial. 19 :492-495.

Sharon, K., Theisen, S.K., DiBartola, S.P., Radin, J.M., Chew, D.J., Tony Buffington, C.A. and Dow, S.W. (1997). Muscle Potassium Content and Potassium Gluconate Supplementation in Normokalemic Cats With Naturally Occurring Chronic Renal Failure. J Vet Intern Med 11 : 212-217.

Silver, J., Russell, J. and Sherwood, L.M. (1985). Regulation by vitamin D metabolites of messenger ribonucleic acid for preproparathyroid hormone in isolated bovine parathyroid cells. Proc Natl Acad Sci USA 82 : 4270-4273.

Smets, P.M., Meyer, E., Maddens, B.E., Duchateau, L.and Daminet, S. (2010). Urinary markers in healthy young and aged dogs and dogs with chronic kidney disease. Journal of Veterinary Internal Medicine 24 : 65-72.

Sparkes, A. H., Caney, S., Chalhoub, S., Elliott, J., Finch, N., Gajanayake, I., Langston, C., Lefebvre, H.P., White, J. and Quimby, J. (2016). ISFM Consensus Guidelines on the Diagnosis and Management of Feline Chronic Kidney Disease. Journal of Feline Medicine and Surgery $18: 219-239$.

Surrena, H. (ed). 2010. Handbook for Brunner \& Suddarth's Textbook of Medical-Surgical 12 $\mathrm{t}^{\mathrm{h}}$ edition. Wolters Kluwer Health/Lippincott Williams \& Wilkins, 530 Walnut Street, Philadelphia, PA 19106. 590.

Sweitzer, N.K. (2003). What Is an Angiotensin Converting Enzyme Inhibitor? Circulation. 108 :e16-e18.

Syme, H.M., Markwell, P.J., Pfeiffer, D. and Elliott, J. (2006). Survival of cats with naturally occurring chronic renal failure is related to severity of proteinuria. $J$ Vet Intern Med. 20 :528-535.

Takahashi, F., Furuichi, T., Yorozu, K., Kawata, S., Kitamura, H., Kubodera, N. and Slatopolsky, E. (2002). Effects of i.v. and oral 1,25-dihydroxy-22-oxavitamin D3 on secondary hyperparathyroidism in dogs with chronic renal failure. Nephrol Dial Transplant 17 [Suppl 10] : 46-52.

Thibodeau, GA. (1999). Anatomy and Physiology. St. Louis, MO. Mosby. : 822-846.

Tomasello, S.(2008). SecondaryHyperparathyroidism and Chronic Kidney Disease. Diabetes Spectrum 21(1): 19-25.

Vaden, S.L. (2005). Glomerular disease. In: Ettinger SJ, Feldman EC, editors. Textbook of Veterinary Internal Medicine. 6th ed. St Louis, Missouri: Saunders (Elsevier) : 1786 -1800. 
Walker, D., Syme, H.M., Markwell, P. and Elliott, J. (2004). Predictors of survival in healthy, nonazotaemic cats. $J$ Vet Intern Med. $18: 417$.

Watanabe, T. And Mishina, M. (2007). Effects of Benazepril Hydrochloride in Cats with Experimentally Induced or Spontaneously Occurring Chronic Renal Failure J. Vet. Med. Sci. 69 (10) : 1015-1023.

Wellman, M.L., DiBartola, S.P. and Kohn, C.W. (2012). Applied physiology of body fluids in dogs and cats. In: DiBartola SP, ed. Fluid, electrolyte, and acid-base disorders in small animal practice. 4th ed. St. Louis (MO): Elsevier Saunders : 15 .

Wolf, A.M. (2015). Chronic Progressive Renal Disease in the Cat: Recognition and Management www.colovma.org/resource.
Yabuki, A., Mizukami, K., Sawa, M., Mitani, S. and Yamato, O. (2011). Early Stage of Chronic Kidney Disease with Renal Injury Caused by Hypertension in a Dog. Case Reports in Veterinary Medicine Vol. 1, Article ID 149648, $: 1-4$.

Yu, S. and Robinson, P.I. (2006). Dietary supplements of vitamins $\mathrm{E}$ and $\mathrm{C}$ and beta-carotene reduce oxidative stress in cats with renal insufficiency. Vet Res Commun. 30 : 403-413.

Yu, S., Gross, K. L. and Allen, T. A. (2006). A renal food supplemented with vitamins $\mathrm{E}, \mathrm{C}$ and beta-carotene reduces oxidative stress and improves kidney function in client-owned dogs with stages 2 or 3 kidney disease. Journal of Veterinary Internal Medicine $20: 1537$. 